\title{
Linagliptin: farmacology, efficacy and safety in type 2 diabetes treatment
}

\author{
Erika Paniago Guedes ${ }^{1,2,7^{*}}$, Alexandre Hohl ${ }^{3,4}$, Thais Gomes de Melo ${ }^{5}$ and Felipe Lauand ${ }^{6}$
}

\begin{abstract}
Type 2 diabetes mellitus (T2DM) has a high prevalence and incidence around the world. The complex pathophysiology mechanism is among the barriers for diabetes treatment. Type 2 diabetes patients have dysfunction in incretin hormones (as glucagon-like peptide-1 or GLP-1, and glucose-dependent insulinotropic polypeptide or GIP). By inhibiting the dipeptidyl peptidase-4 (DPP-4) enzyme, it is possible to slow the inactivation of GLP-1 and GIP, promoting blood glucose level reduction in a glucose-dependent manner. Linagliptin is a highly specific and potent inhibitor of DPP-4 that is currently indicated for the treatment of type 2 diabetes. Clinical studies with linagliptin demonstrated efficacy in reducing glycated hemoglobin (HbA1c) levels in type 2 diabetes patients, while maintaining a placebo-like safety and tolerability profile. Linagliptin has an interesting pharmacokinetic profile in terms of its predominantly non-renal elimination and the main implication of this characteristic is that no dose adjustment is necessary in patients with renal disease. Also, no dose adjustment is required in patients with hepatic insufficiency, as well in elderly or obese patients. This article will review the pharmacokinetic profile, efficacy data and safety aspects of linagliptin in type 2 diabetes patients.
\end{abstract}

Keywords: DPP-4 inhibitor, Linagliptin, Efficacy, Safety, Renal impairment, Type 2 diabetes

\section{Introduction}

In recent decades, type 2 diabetes mellitus (T2DM) has reached epidemic proportions in all regions of the world, with increasing prevalence and incidence rates, in parallel to the obesity epidemic and the dissemination of occidental lifestyle [1]. It is estimated that in 2030, T2DM will achieve about 300 million people worldwide [2]. The micro- and macrovascular complications, associated with chronic hyperglycemia, represent a major public health problem. Cardiovascular diseases, blindness, renal failure and limb amputations are responsible for frequent hospitalizations and disabilities, resulting in high economic cost for patients and payers [1]. Early and intensive glycemic control is associated with reduction of these complications $[3,4]$.

The pathophysiological defects involved in T2DM are numerous and complex. Insulin resistance (IR) is an event that precedes and predicts the hyperglycemia

\footnotetext{
*Correspondence: erikapaniago@uol.com.br

'Endocrinologist Board of Metabolism Outpatient Clinic from the 481 State Institute for Diabetes and Endocrinology (IEDE/RJ), Rio de Janeiro, RJ, Brazil ${ }^{2}$ Department of Endocrinology of Medical School of Graduate Studies, Pontifical Catholic University of Rio de Janeiro (PUC/RJ), Rio de Janeiro, RJ, Brazil

Full list of author information is available at the end of the article
}

characteristic of T2DM, persisting throughout the course of the disease, and is therefore a therapeutic target in the whole evolution process. The liver, muscles, and fat tissue are directly involved in the IR mechanism [5]. The insulin deficit is the mechanism that promotes the increase of blood glucose levels, and at diagnosis of diabetes, the patient has already lost more than $80 \%$ of beta-cell function [5]. However, new mechanisms are reformulating the pathophysiological concept of T2DM, for example, the defect in the incretin system (Glucagon-like peptide-1 or GLP-1, and Gastric inhibitory polypeptide or GIP), promoting hyperglycemia by less stimulation of insulin secretion by pancreatic beta-cells, and less suppression of glucagon release by pancreatic alpha-cells [1]. GLP-1 and GIP are degraded by the dipeptidyl peptidase-4 (DPP-4) enzyme immediately after their secretion by intestinal Lcells [5]. DPP-4 inhibition is an important target for the T2DM treatment, providing increased GLP-1 concentration, with consequent increase of insulin secretion by pancreatic $\beta$ cells and reduction of glucagon secretion from pancreatic $\alpha$-cells, which in turn reduces hepatic glucose output [6].

\section{Biomed Central}

(c) 2013 Guedes et al.; licensee BioMed Central Ltd. This is an Open Access article distributed under the terms of the Creative Commons Attribution License (http://creativecommons.org/licenses/by/2.0), which permits unrestricted use, distribution, and reproduction in any medium, provided the original work is properly cited. 
The linagliptin is a DPP-4 inhibitor (or gliptin) with pharmacokinetic and pharmacodynamic characteristics that differenciate it from other inhibitors on the market [6]. In this article, aspects of the linagliptin pharmacology will be reviewed, in addition to safety, tolerability and efficacy data on monotherapy or combination therapy.

\section{Pharmacological aspects Chemical structure}

The DPP-4 inhibitors can be divided, according to their chemical structure, into those that mimic the DPP-4 molecule (vildagliptin and saxagliptin) and those that do not (sitagliptin, alogliptin, and linagliptin). They inhibit the DPP-4 enzyme by competition, acting extra-cellularly [7]. The chemical structure of linagliptin $\left(\mathrm{C}_{25} \mathrm{H}_{28} \mathrm{~N}_{8} \mathrm{O}_{2}\right)$ has a xanthine base, differing from other drugs of the same class, and may reflect differences in pharmacokinetic and pharmacodynamic properties (Figure 1) $[8,9]$. The linagliptin also exhibits excellent selectivity for DPP-4 enzyme versus DPP-8 (40,000-fold) and DPP-9 (>10,000fold), and a low selectivity for fibroblast activation protein- $\alpha$ (FAP- $\alpha)$ (Table 1) [6,7]. However, the DPP-8 and DPP-9 enzymes are intracellular and there is no evidence that less selective inhibitors, such as saxagliptin and vildagliptin, cross the cell membrane. Thus, despite questioning the possibility of an increased risk of adverse events with less selective inhibitors, the clinical relevance and significance of this selectivity are not established [6].

\section{Pharmacokinetic and pharmacodynamic data}

Linagliptin shows modest oral bioavailability, but is rapidly absorbed $[9,10]$. The maximum plasma concentration $\left(\mathrm{C}_{\max }\right)$ at steady state is reached on average 1.5 hours after administration of linagliptin $5 \mathrm{mg}$, once daily [11]. Linagliptin half-life $\left(t_{1 / 2}\right)$ is 131 hours [12]. No relevant food effects were observed on the absorption profile of linagliptin [10].

A strong binding of the inhibitor to the DPP-4 enzyme is important from the pharmacological point of view, to
Table 1 In vitro selectivity of DPP-4 inhibitors (fold selectivity for DPP-4 versus other enzymes) (Adapted from Gupta et al.) [8]

\begin{tabular}{llll}
\hline Idpp4 & FAP $_{\mathbf{a}}$ & DPP-8 & DPP-9 \\
\hline Vildagliptin & 285 & 270 & 32 \\
\hline Saxagliptin & $?$ & 390 & 77 \\
\hline Sitagliptin & $>5.500$ & $>2.660$ & $>5.550$ \\
\hline Alogliptin & $>14.000$ & $>14.000$ & $>14.000$ \\
\hline Linagliptin & 89 & 40.000 & $>10.000$
\end{tabular}

$F_{A} P_{a}$ Fibroblast activation protein ${ }_{a}$ DPP-8 Dipeptidyl peptidase-8, DPP-9 Dipeptidyl peptidase-9.

enable a 24-hour inhibition profile and the once-daily dosing. Linagliptin is a competitive, selective and reversible inhibitor, with ligand/receptor association $\left(\mathrm{K}_{\mathrm{i}}\right)$ of $1 \mathrm{nmol} / \mathrm{L}$, indicating strong binding, and a low dissociation rate of the enzyme $[8,9]$. The maximal efficacy for in vitro DPP-4 inhibition is similar among all DPP-4 inhibitors, however linagliptin has greater potency (half maximal [50\%] inhibitory concentration or $\mathrm{IC}_{50}=\sim 1 \mathrm{nM}$ for linagliptin versus $19,62,50$ and $24 \mathrm{nM}$ for sitagliptin, vildagliptin, saxagliptin and alogliptin, respectively) [9]. In healthy male volunteers, linagliptin (2.5-600 mg) demonstrated dose-dependent inhibition of DPP-4 over 24 hours with a $5 \mathrm{mg}$ dose inhibiting $86.1 \%$ of the enzyme activity [13]. It is important to note that the inhibition $\geq 80 \%$ of DPP-4 activity is the level which leads to the maximum glucose reduction [14].

In plasma, most gliptins exhibit low binding rate to proteins [9]. Linagliptin, in turn, extensively binds to plasma proteins, and at the therapeutic dose of $5 \mathrm{mg}$, most of the drug is bound to proteins [9]. Among the drugs in this class, linagliptin, sitagliptin and alogliptin do not show appreciable metabolism in vivo; about $80 \%$ of the dose is eliminated unchanged [9]. In plasma, only the pharmacologically inactive metabolite CD18790 represents over $10 \%$ of the total drug concentration [15].

Unlike other DPP-4 inhibitors, linagliptin excretion is not performed by the kidneys, but rather through the

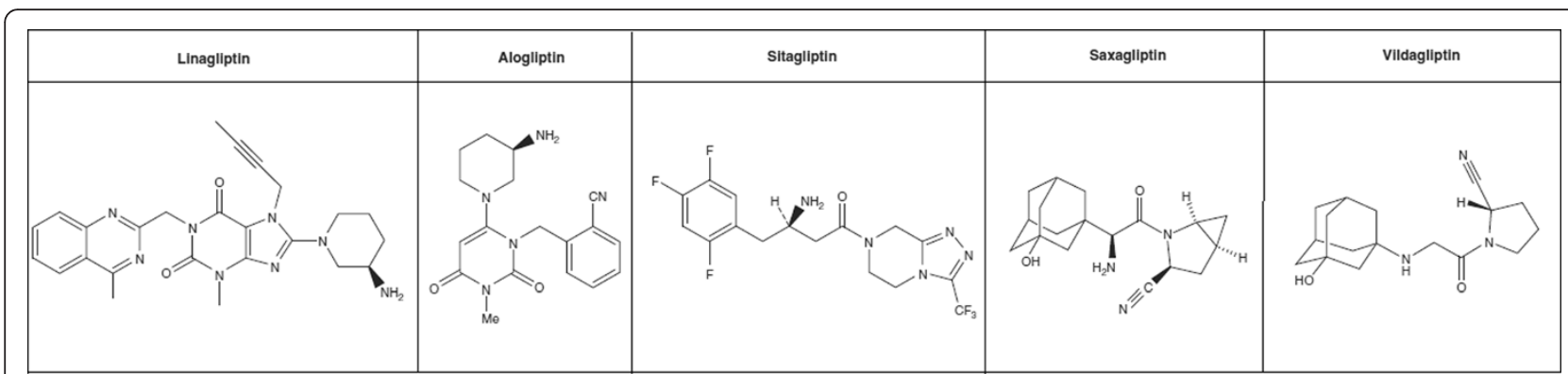

Figure 1 Chemical structure of the DPP-4 inhibitors $[9,10]$. 
enterohepatic system, unchanged [8]. This method of excretion may be in part because of the high plasma protein binding [9]. The implication of this mode of linagliptin excretion is that in patients with kidney disease, no dose adjustment is required [8].

\section{Clinical studies: efficacy assessment Monotherapy}

Although metformin is the first-line drug in the early pharmacological treatment of T2DM, some patients do not tolerate the drug, or exhibit contraindications [16]. In these cases, the DPP-4 inhibitors such as linagliptin can be an effective option for use as monotherapy. The efficacy of linagliptin as monotherapy, compared to placebo, was assessed in two studies of 12 and 24 weeks $[17,18]$. The linagliptin was significantly more effective than placebo in reducing glycated hemoglobin (HbA1c). Also independent of baseline HbA1c, the results were favorable for linagliptin; for baseline $\mathrm{HbA1c}$ $\geq 9.0 \%, 8.0 \%$ to $<9.0 \%, 7.5 \%$ to $<8.0 \%$ and $<7.5 \%$, the respective placebo-adjusted mean changes were $-1.1 \%$ ( $\mathrm{p}<0.0001),-0.71 \%(\mathrm{p}<0.0001),-0.55 \%(\mathrm{p}<0.005)$ and $-0.57(\mathrm{p}<0.0001)$ [18].

The results of linagliptin monotherapy were also better than placebo in the secondary endpoints. There was more reduction in fasting plasma glucose (FPG) and 2hour postprandial glucose (2hPPG) in the linagliptin group. The adjusted mean change in FPG was -1.3 $\mathrm{mmol} / \mathrm{L}(\mathrm{p}<0.0001)$, and in $2 \mathrm{hPPG}$ was $-3.2 \mathrm{mmol} / \mathrm{L}$ $(\mathrm{p}<0.0001)$. The percentage of patients with HbA1c $<7 \%$ after 24 weeks was $25.2 \%$ (77/306) in the linagliptin group compared to $11.6 \%(17 / 147)$ in the placebo group $(\mathrm{OR}=$ $2.9, \mathrm{p}=0.0006)[18]$. Besides, there was significant improvement in $\beta$-cell function markers (HOMA- $\% \beta, \mathrm{C}$ peptide, proinsulin-to-insulin ratio, and disposition index [DI]) in those receiving linagliptin $[17,18]$.

Kawamori et al. also compared linagliptin monotherapy with voglibose, an $\alpha$-glucosidase inhibitor, in a 26 -week study [17]. More patients receiving linagliptin achieved HbA1c $\leq 7 \%$ (30.3\%) when compared to voglibose (22.2\%) [10]. The percentage of patients achieving a reduction $\geq$ $0.5 \%$ in HbA1c with linagliptin $(57.2 \%)$ was also greater than those with voglibose $(37.7 \%)(\mathrm{p}<0.0001)[10]$.

\section{Combination therapy}

- Combination with metformin Metformin is considered first-line therapy in most guidelines around the world. Following 3 years of T2DM diagnosis, approximately $50 \%$ of patients will require combination therapy [19]. Thus, the combination of metformin with another agent which complements its action will be performed in most type 2 diabetes patients. Graefe-Mody et al. evaluated in a randomized, open-label, crossover, single-center study, the potential pharmacokinetic and pharmacodynamic interaction between metformin and linagliptin. The coadministration of metformin $850 \mathrm{mg}$, three times daily and linagliptin (10 mg once daily) did not modify the pharmacological profile of each drug alone. This study suggested that the combination of metformin and linagliptin can be done safely in patients with T2DM, without requiring dose adjustment [20].

In a 24-week study with about 700 patients, the addition of linagliptin to the therapeutic regimen in diabetic patients inadequately controlled on metformin, HbA1c reduction from baseline was $0.64 \%$ with the linagliptin versus placebo. The Figure 2 exhibits the HbA1c change over time [21]. The adjusted mean reduction in FPG was $1.2 \mathrm{mmol} /$ $\mathrm{L}$ in the group with added linagliptin, and in 2hPPG was $3.7 \mathrm{mmol} / \mathrm{L}$ ( $\mathrm{p}<0.0001$ for all comparisons) [22]. In another 12-week assessment, linagliptin $5 \mathrm{mg}$ (single daily dose) was added to the metformin treatment ( $\mathrm{n}=333$ patients), and was significantly more effective than placebo and the 1-mg or 10-mg doses [23].

Haak et al. reported the findings of early combination of linagliptin and metformin in treatment-naïve diabetic patients, in a 24-week double-blind study [22]. Compared to metformin monotherapy (1000 mg), the early combination of metformin $(1000 \mathrm{mg})$ and linagliptin $(5 \mathrm{mg})$ was more effective in reducing HbA1c $(-1.7 \%$ versus $-0.8 \%, \mathrm{p}<0.0001)$. Substantial reduction in FPG from baseline to Week 24 was found with the combination therapy [22].

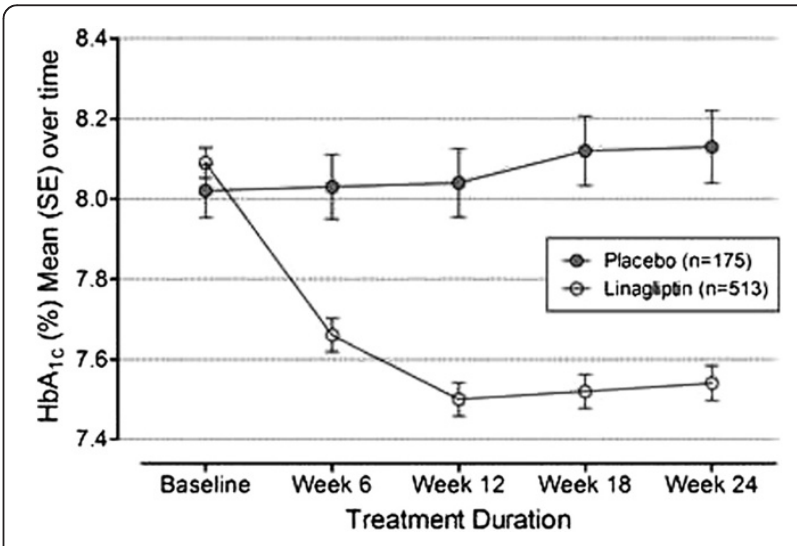

Figure 2 Change over time in $\mathrm{HbA} 1 \mathrm{c}$, following treatment with linagliptin $\mathbf{5 g}$ or placebo for $\mathbf{2 4}$ weeks (reproduced from Taskinem et al.) [21]. 
- Combination with glitazone

Linagliptin was also evaluated in combination with pioglitazone, in a 24-week investigation $(\mathrm{n}=389$ patients). The addition of linagliptin (5 $\mathrm{mg}$ ) to pioglitazone (30 mg), both administered in a single daily dose, caused an adjusted mean placebocorrected reduction of $0.5 \%$ in $\mathrm{HbA} 1 \mathrm{c}$ levels from baseline at the end of 12 weeks, remaining constant until the 24th week. The group receiving the linagliptin/pioglitazone combination showed more significant reductions in FPG than placebo/ pioglitazone group $(\mathrm{p}<0.0001)$ [24]. More patients in the linagliptin/pioglitazone group (42.9\%) achieved the target HbA1c $<7 \%$, compared to the placebo-pioglitazone group $(30.5 \%, \mathrm{p}<0.0051)$. The $\mathrm{HbA1c}$ reduction was greater in patients with baseline $\mathrm{HbA} 1 \mathrm{c} \geq 9 \%$ and treated with linagliptin in combination with pioglitazone (-1.49\%). Body weight remained stable up to 24 weeks in the two groups. This combination can be interesting, even for early therapy in patients with an intolerance or contraindication to metformin.

- Combination with sulfonylurea In patients inadequately controlled on sulfonylurea alone, the addition of linagliptin $5 \mathrm{mg}$ (single daily dose) proved more effective than the combination with placebo [25]. In this double-blind study, 245 patients were randomized to receive linagliptin $(\mathrm{n}=161)$ or placebo $(\mathrm{n}=84)$ for 18 weeks. The HbA1c reductions were significant in favor of linagliptin at Weeks 6, 12 and $18(\mathrm{p}<0.0001)$ [26].

- Triple Combination

The progressive failure of the pancreatic $\beta$-cell function contributes to evolutive character of the disease and the need for therapeutic adjustment. After 3 years of diagnosis, about $50 \%$ of diabetic patients will require combination therapy [19]. In a randomized, double-blind, placebo-controlled study, investigators have screened 1058 T2DM patients inadequately controlled on metformin (>1500 mg/day) and sulfonylurea (maximum tolerated dose) to receive the combination with linagliptin $5 \mathrm{mg}$ (single daily dose) or placebo [27]. Assessing the total patients included, the adjusted mean change in HbA1c level was $-0.72 \%$ in the linagliptin group compared with $-0.10 \%$ in the placebo group, resulting in a difference of $-0.62 \%(\mathrm{p}<0.0001)$ with placebo. Fewer patients receiving linagliptin required rescue therapy compared with placebo (5.4 versus $13.0 \%$ ). More patients on linagliptin also achieved the target HbA1c. The importance of this study in practice is the possibility to improve glycemic control in patients already receiving two oral antidiabetic agents and who are outside the proposed targets [27].

\section{Comparison with sulfonylurea}

The DPP-4 inhibitors promote glucose-dependent insulin secretion, i.e., in the presence of lower blood glucose values, the insulin release is not expected, which contributes to reduce the risk of hypoglycemia [16]. The sulfonylureas, in turn, are more associated with hypoglycemia since they do not exhibit glucose-dependent mechanism of action. In a 12-week analysis, 333 T2DM patients inadequately controlled on metformin monotherapy were randomized to receive linagliptin or glimepiride, in a single daily dose [25]. After 12 weeks, HbA1c has decreased both in the linagliptin or glimepiride groups. This study showed that linagliptin has the same efficacy as sulfonylureas, without risk of weight gain and hypoglycemia [25].

\section{Safety and tolerability Adverse events}

- Hypoglycemia DPP-4 inhibitors have a low risk of hypoglycemia due to their effect as glucose-dependent insulin secretagogue. The incidence of hypoglycaemia was $8.2 \%$ in patients receiving linagliptin and $5.1 \%$ in those receiving placebo. The somewhat higher incidence of hypoglycaemia associated with linagliptin was almost exclusively attributable to the combination with sulphonylurea. In studies where patients were receiving sulphonylurea, the incidence of hypoglycaemia was $20.7 \%$ and $13.3 \%$ in the linagliptin- and placebo-treated groups, respectively; notably, $38 \%$ of patients on sulphonylurea background therapy accounted for $96 \%$ of all hypoglycaemic events in the linagliptin-treated group [28]. As observed with other gliptins, the combination with linagliptin to patients inadequately controlled on metformin + sulfonylurea showed a higher occurrence of hypoglycemia than the placebo group (22.7\% versus 14.8\%) [27].

- Weight gain The T2DM treatment with glitazone, sulfonylurea, or insulin may be associated with weight gain. Most T2DM patients are overweight or obese, so it is not desirable to gain additional weight due to the treatment. DPP-4 inhibitors have a neutral effect on body weight [8]. Linagliptin showed no weight increase in monotherapy or in combination with metformin. In combination with pioglitazone, the linagliptin was associated with greater weight gain than placebo $(2.3 \mathrm{~kg}$ versus $1.2 \mathrm{~kg}, \mathrm{p}<0.01$ ), in a 24-week study, but these changes were minimal from baseline [24]. There was also no change in waist circumference with linagliptin treatment [24]. 
- Other adverse events

The adverse events most frequently reported with DPP-4 inhibitors are mild infections (such as nasopharyngitis, urinary tract infection, and upper respiratory tract infections) and diarrhoea, back pain, headache and hypertension. Data presented with linagliptin indicate an overall incidence similar to placebo for these most frequently observed adverse events [28].

In 2008, the FDA (Food and Drug Administration) recommended the inclusion of a warning on the package insert of some drugs acting on the incretin system, after case reports of pancreatitis with the use of GLP-1 analogs [29]. Postmarketing analyses have also identified isolated cases of pancreatitis with DPP-4 inhibitors, but a cause-effect relationship was not identified. It is important to consider that patients with T2DM and hypertriglyceridemia exhibit increased risk of pancreatitis [7]. In clinical studies, 8 pancreatitis cases were reported in 4687 patients on linagliptin and no cases among 1183 patients receiving placebo; however, no relationship between linagliptin and pancreatitis has been established [13].

Despite the therapeutic dose used in practice being $5 \mathrm{mg}$, in a single daily dose, there seems to be no increased incidence of adverse events with increasing doses of linagliptin. Also, no changes in laboratory parameters or vital signs were observed in different studies with the drug. Moreover, the incidence of cutaneous and subcutaneous changes in linagliptin clinical trials was low when compared to placebo $(0-1.3 \%$ versus $0-0.9 \%)$ [13].

\section{Patients with renal impairment}

Linagliptin administration to patients with renal impairment does not require dosage adjustment [6]. When administered in a $5 \mathrm{mg}$ dose, less than $1 \%$ of linagliptin is excreted unchanged in the urine. Thus, in therapeutic dose, renal excretion is a minor route of elimination for linagliptin, unlike other DPP-4 inhibitors [30]. When tested in patients with mild (creatinine clearance $>50$ to $\geq$ $80 \mathrm{~mL} / \mathrm{min}$ ), moderate (creatinine clearance $>30$ to $\leq 50$ $\mathrm{mL} / \mathrm{min}$ ), and severe (creatinine clearance $<30 \mathrm{~mL} / \mathrm{min}$ ) renal impairment, in addition to the end-stage renal disease (creatinine clearance $<30 \mathrm{~mL} / \mathrm{min}$ on hemodialysis), renal excretion of linagliptin remained unchanged and represents less than 7\% in all groups [31]. In an analysis of 3 Phase III, randomized, placebo-controlled studies, the effect of renal function on the efficacy and safety of linagliptin was evaluated. Patients $(\mathrm{n}=2141)$ were grouped according to renal function, and it was found that reductions in $\mathrm{HbAlc}$ with linagliptin did not differ among groups (mild, moderate, or severe renal impairment), as well as adverse event occurrences that were similar to placebo [31,32].

\section{Patients with liver failure}

Linagliptin administration to patients with liver failure does not require dose adjustment. Although reductions occur in the linagliptin pharmacokinetic parameters as the liver failure degree increases, this has no impact on DPP-4 inhibition [6].

\section{Elderly patients}

No changes were observed in safety and tolerability of linagliptin in patients aged over 65 years [6].

\section{Cardiovascular safety}

The main cause of mortality in T2DM patients is cardiovascular disease (CVD) [33]. The gliptins may exert beneficial cardiovascular effects through different mechanisms (Table 2) [34]. Recent studies also demonstrated that intensive control may be associated with increased cardiovascular (CV) risk; therefore, another potential benefit of gliptins would be a low risk of hypoglycemia [35]. In studies using animal models, activation of GLP-1 receptor is associated with limiting the size of the area of myocardial infarction (MI) [36]. Furthermore, linagliptin has anti-oxidant properties, probably due to its xanthine-based molecular structure [37]. Even when administered in supratherapeutic doses, linagliptin does not prolong the QT interval [38].

A recent meta-analysis has assessed the cardiovascular safety profile of linagliptin in patients who participated in 8 Phase III studies. Of the 5239 patients, 3319 received linagliptin, and 1920 received a comparator (placebo, glimepiride, voglibose) [35]. A composite of CV death, stroke, MI, or hospitalization for unstable angina was considered as the primary endpoint. In the linagliptin group, the primary endpoint occurred in $11(0.3 \%)$ patients, whereas in the comparator group there were 23 cases (1.2\%), demonstrating lower risk in those who received linagliptin. An important conclusion is that, as other DPP4 inhibitors have also demonstrated, linagliptin shows no increase in CV risk [35]. At present, various studies with DPP-4 inhibitors are currently ongoing to evaluate the safety and effects on cardiovascular endpoints (Table 3) [8].

\section{Drug interaction}

In general, DPP-4 inhibitors have not demonstrated a significant activation or inhibition of CYP system enzymes,

Table 2 Potential cardiovascular benefits of DPP-4 inhibitors [38]

\begin{tabular}{ll}
\hline $\begin{array}{l}\text { Neutral effect on body } \\
\text { weight }\end{array}$ & $\begin{array}{l}\text { Improved glycemic control, } \\
\text { including PPG reduction }\end{array}$ \\
\hline $\begin{array}{l}\text { Decreased systolic blood } \\
\text { pressure }\end{array}$ & Improved lipid profile \\
\hline $\begin{array}{l}\text { Reduction in C-reactive protein } \\
\text { (CRP) }\end{array}$ & $\begin{array}{l}\text { Improvement of endothelial } \\
\text { dysfunction }\end{array}$ \\
\hline
\end{tabular}


Table 3 DPP-4 inhibitors and cardiovascular risk: ongoing studies (adapted from [8])

\begin{tabular}{ll}
\hline Sitagliptin & $\begin{array}{l}\text { TECOS: Trial Evaluating Cardiovascular Outcomes with } \\
\text { Sitagliptin }\end{array}$ \\
\hline Saxagliptin & $\begin{array}{l}\text { SAVOR: Saxagliptin Assessment of Vascular Outcomes } \\
\text { Recorded in Patients with Diabetes Mellitus Trial }\end{array}$ \\
\hline Alogliptin & EXAMINE: Examination of Cardiovascular Outcomes: \\
& $\begin{array}{l}\text { Alogliptin vs Standard of Care in Patients with Type 2 } \\
\text { Diabetes Mellitus and Acute Coronary Syndrome }\end{array}$ \\
\hline Linagliptin & CAROLINA: Cardiovascular Outcome Study of \\
& Linagliptin Versus Glimepiride in Patients with Type 2 \\
& Diabetes \\
\hline
\end{tabular}

suggesting low potential for interaction with drugs metabolized by this pathway (except saxagliptin) [9]. Linagliptin is a substrate for CYP3A4/5, and CYP3A4 inhibition or induction by concomitant administration of other drugs would not cause significant change in exposure to linagliptin. Additionally, as linagliptin is just a weak competitive inhibitor of CYP3A4, there would be a less than 2-fold decrease in the clearance of other drugs metabolized by this pathway, so linagliptin is considered as having low potential for clinically relevant interactions [15].

In different pharmacokinetic drug-drug interaction studies, linagliptin exhibited low potential for drug interaction [10]. Linagliptin did not change the pharmacokinetic steady state of ethinyl estradiol, levonorgestrel, digoxin, warfarin, glyburide, pioglitazone, simvastatin, and metformin [10]. Rifampicin, in turn, can reduce the exposure to linagliptin, suggesting that linagliptin efficacy may be reduced by concomitant use of these two drugs [12].

\section{Conclusions}

Currently, DPP-4 inhibitors represent an important tool in the T2DM therapeutic setting, both for their efficacy in glycemic control, as well as for their safety profile. Regarding the effect on glycemic control, no significant differences have been evidenced among the gliptins. Linagliptin is a potent, long-acting, orally active DPP-4 inhibitor, with demonstrated efficacy as monotherapy and in combination therapy with other oral antidiabetic agents, when administered in a single daily dose. The primarily non-renal route of elimination of linagliptin differenciate it from other drugs in the same class; patients with kidney disease of any degree do not require dose reduction of linagliptin. The risk of adverse events with linagliptin monotherapy is similar to placebo. Its effect on body weight is considered neutral and the hypoglycemia occurrence is very low. Therefore, linagliptin can contribute to the achievement of glycemic targets, with safety and tolerability, even in special difficult-to-manage situations, as in those patients with renal impairment.

\section{Abbreviations}

T2DM: Type 2 diabetes mellitus; GLP-1: Glucagon-like peptide-1; GIP: Glucose-dependent insulinotropic polypeptide; DPP-4: Dipeptidyl peptidase-4; HbA1c: Glycated hemoglobin; $C_{\text {max }}$ : Maximum plasma concentration; $\mathrm{t}_{1 / 2}$ : Half-life; $\mathrm{IC}_{50}$ : Half maximal (50\%) inhibitory concentration; FPG: Fasting plasma glucose; 2hPPG: 2-hour postprandial glucose; FDA: Food and drug administration; CVD: Cardiovascular disease; CV: Cardiovascular; Ml: Myocardial Infarction.

\section{Competing interests}

Guedes EP has received lecture and/or consultancy fees from companies with interest in type 2 diabetes therapies (Astra Zeneca, Bristol-Meyers-Squibb, Novo Nordisk, Boehringer-Ingelheim, Torrent and Abbott).

Hohl A has received lecture and/or consultancy fees from companies with interest in type 2 diabetes therapies (Merck Sharp Dohme, Bristol-Meyers-Squibb, Novartis, Merck Serono, Boehringer-Ingelheim, Eli Lilly, Sanofi and Abbott) Melo TG is medical manager for Boehringer-Ingelheim do Brasil. Lauand $F$ is medical manager for Eli Lilly do Brasil.

\section{Authors' contributions}

All authors participated equally in the development of this paper. All authors also read and approved the final manuscript.

\section{Author details}

${ }^{1}$ Endocrinologist Board of Metabolism Outpatient Clinic from the 481 State Institute for Diabetes and Endocrinology (IEDE/RJ), Rio de Janeiro, RJ, Brazil. ${ }^{2}$ Department of Endocrinology of Medical School of Graduate Studies, Pontifical Catholic University of Rio de Janeiro (PUC/RJ), Rio de Janeiro, RJ, Brazil. ${ }^{3}$ Federal University of Santa Catarina (UFSC), Florianopolis, SC, Brazil. ${ }^{4}$ Brazilian Society of Endocrinology and Metabolism - Santa Catarina state (SBEM-SC) - 2011/2012, Florianopolis, SC, Brazil. ${ }^{5}$ Boehringer Ingelheim, São Paulo, SP, Brazil. ${ }^{6}$ Eli Lilly, São Paulo, SP, Brazil. ${ }^{7}$ Avenida das Américas, no. 2901, sala 305, Edifício Barra Business, Barra da Tijuca, Rio de Janeiro, RJ 489 22631-030, Brazil.

Received: 8 February 2013 Accepted: 13 May 2013

Published: 22 May 2013

\section{References}

1. Inzuchi SE, Bergenstal RM, Buse JB, Diamant M, Ferrannini E, Nauck M, Peters AL, Tsapas A, Wender R, Matthews DR: Management of hyperglycemia in type 2 diabetes: a patient-centered approach. Position statement of the American Diabetes Association (ADA) and the European Association for the Study of Diabetes (EASD). Diabetes Care 2012, 35(6):1364-1379.

2. Wild S, Roglic G, Green A, Sincree R, King H: Global prevalence of diabetes: estimates for the year 2000 and projections for 2030. Diabetes Care 2004, 27:1047-1053.

3. Stratton IM, Adler Al, Neil HA, Matthews DR, Manley SE, Cull CA, Hadden D, Turner RC, Holman R: Association of glycaemia with macrovascular and microvascular complications of type 2 diabetes (UKPDS 35): prospective observational study. BMJ 2000, 321:405-412.

4. Holman RR, Paul SK, Bethel MA, Matthews DR, Neil HAW: 10-Year follow-up of intensive glucose control in Type 2 Diabetes. N Engl J Med 2008, 359:1577-1589.

5. DeFronzo AR: From the triumvirate to the ominous octet: a new paradigm for the treatment of type 2 diabetes melitus. Diabetes 2009, 58:773-795.

6. Kalra S, Unnikrishnan AG, Agrawal N, Singh AK: Linagliptin and newer DPP4 inhibitors: newer uses and newer indications. Recent Pat Endoc Metab Immune Drug Discov 2011, 5:197-202.

7. Gupta V, Kalra S: Choosing a gliptin. Indian J Endocrinol Metab 2011, 14(4):298-308.

8. Scheen AJ: A review of gliptins in 2011. Expert Opn Pharmacolther 2012 13(1):81-99.

9. Deacon CF, Holst JJ: Linagliptin, a xanthine-based dipeptidyl peptidase-4 inhibitor with an unusual profile for the treatment of type 2 diabetes. Expert Opin Investig Drugs 2010, 19(1):133-140.

10. Deeks ED: Linagliptin: a review of its use in the management of type 2 diabetes mellitus. Drugs 2012, 72(13):1793-1824.

11. Heise T, Graefe-Mody EU, Huttner S, Ring A, Trommeshauser D, Dugi KA: Pharmacokinetics, pharmacodynamics and tolerability of multiple oral 
doses of linagliptin, a dipeptidyl peptidase- 4 inhibitor in male type 2 diabetes patients. Diabet Obes Metab 2009, 11:786-794.

12. Forst $\mathrm{T}$, Pfutzner $\mathrm{A}$ : Linagliptin, a dipeptidyl peptidase-4 inhibitor with a unique pharmacological profile, and efficacy in a broad range of patients with type 2 diabetes. Expert Opin Pharmacother 2012, 13(1):101-110

13. Huttner S, Graefe-Mody EU, Withopf B, Ring A, Dugi KA: Safety, tolerability, pharmacokinetics and pharmacodynamics of single oral doses of Bl1356, an inhibitor of dipeptidyl peptidase 4 , in healthy male volunteers. J Clin Pharmacol 2008, 48(10):1171-1178.

14. Cox ME, Rowell J, Corsino L, Green JB: Dipeptidyl peptidase-4 inhibitors in the management of type 2 diabetes: safety, tolerability, and efficacy. Drug Healthc Patient Saf 2010, 2(1):7-19.

15. Blench S, Ludwig-Schwellinger E, Grafe-Mody U, Withopf B, Wagner K: The metabolism and disposition of the oral dipeptidyl peptidase-4 inhibitor, linagliptin, in humans. Drug Metab Dispos 2010, 38:667-678.

16. Barnett AH: Linagliptin: a novel dipeptidyl peptidase 4 inhibitor with a unique place in therapy. Adv Ther 2011, 28(6):447-459.

17. Kawamori R, Inagaki N, Araki E, Watada H, Hayashi N, Horie Y, Sarashina A, Gong Y, von Eynatten M, Woerle HJ, Dugi KA: Linagliptin monotherapy provides superior glycaemic control versus placebo or voglibose with comparable safety in japanese patients with type 2 diabetes mellitus: a randomized, placebo and active comparator-controlled, double-blind study. Diabetes Obes Metab 2012, 14(4):348-357.

18. Del Prato S, Barnett AH, Huisman H, Neubacher D, Woerle HJ, Dugi KA Effect of linagliptin monotherapy on glycemic control and markers of beta cell function in patients with inadequately controlle type 2 diabetes: a randomized controlled trial. Diabetes Obes Metab 2011, 13:258-267.

19. Turner RC, Cull CA, Frighi V, Holman RR: Glycemic control with diet, sulfonylurea, metformin, or insulin in patients with type 2 diabetes mellitus: progressive requirement for multiple therapies. (UKPDS 49). JAMA 1999, 281:2005-2012.

20. Graefe-Mody EU, Padula S, Ring A, Withopf B, Dugi KA: Evaluation of the potential for steady-state pharmacokinetic and pharmacodynamics interactions between the DPP-4 inhibitor linagliptin and metformin in healthy subjects. Curr Med Res Opin 2009, 25(8):1963-1972.

21. Taskinen MR, Rosenstock J, Tamminen I, Kubiak R, Patel S, Dugi KA, Woerle $\mathrm{HJ}$ : Safety and efficacy of linagliptin as add-on therapy to metformin in patients with type 2 diabetes: a randomized, double-blind, placebo-controlled study. Diabetes Obes Metab 2011, 13(1):65-74.

22. Haak $T$, Meinicke $T$, Jones $R$, Weber $S$, von Eynatten $M$, Woerle $H J$ : Initial combination of linagliptin and metformin improves glycemic control in type 2 diabetes: a randomized, double-blind, placebo-controlled study. Diabetes Obes Metab 2012, 14(6):565-574.

23. Forst T, Uhlig-Laske B, Ring A, Graefe-Mody EU, Friedrich C, Herbach $\mathrm{K}_{\text {, }}$ Woerle H-J, Dugi K: Linagliptin (BI1356), a potent and selective DPP-4 inhibitor, is safe and efficacious in combination with metformin in patients with inadequately controlled Type 2 diabetes. Diabet Med 2010 27(12):1409-1419.

24. Gomis R, Espadero RM, Jones R, Woerle HJ, Dugi KA: Efficacy and safety of initial combination therapy with linagliptin and pioglitazone in patients with inadequately controlled type 2 diabetes: a randomized, double-blind, placebo-controlled study. Diabetes Obes Metab 2011, 13:653-661.

25. Gallwitz B, Rosenstock J, Rauch T, Bhattacharya S, Patel S, von Eynatten M, Dugi KA, Woerle HJ: 2-year efficacy and safety of linagliptin compared with glimepiride in patients with type 2 diabetes inadequately controlled on metformin: a randomised, double-blind, non-inferiority trial. Lancet 2012, 380(9840):475-483.

26. Gomis R, Owens DR, Taskinen MR, Del Prato S, Patel S, Pivovarova A Schlosser A, Woerle HJ: Long-term safety and efficacy of linagliptin as monotherapy or in combination with other oral glucose-lowering agents in 2121 subjects with type 2 diabetes: up to 2 years exposure in 24-week phase III trials followed by a 78-week open-label extension. Int J Clin Pract 2012, 66(8):731-740.

27. Owens DR, Swallon R, Dugi KA, Woerle HJ: Efficacy and safety of linagliptin in persons with type 2 diabetes inadequately controlled by a combination of metformin and sulphonylurea: a 24-week randomized study. Diabet Med 2011, 28:1352-1361.

28. Schernthaner G, Barnett AH, Emser A, Patel S, Troost J, Woerle HJ, von Eynatten M: Safety and tolerability of linagliptin: a pooled analysis of data from randomized controlled trials in 3572 patients with type 2 diabetes mellitus. Diabetes Obes Metab 2012, 14(5):470-8

29. FDA: Byeta (Safety). http://www.fda.gov/safety/medwatch/safetyinformation/ safetyalertsforhumanmedical products/ucm079781.htm.

30. Scheen AJ: Linagliptin for the treatment of type 2 diabetes (pharmacokinetic evaluation). Expert Opin Drug Metab Toxicol 2011, 7(12):1561-1576

31. Graefe-Mody U, Friedrich C, Port A, et al: Effect or renal impairment on the pharmacokinetics of the dipeptidyl peptidase-4 inhibitor linagliptin. Diabetes Obes Metab 2011, 13:939-946.

32. McGill JB, Sloan L, Newman J, Patel S, Sauce C, Von Eynatten M, Woerle HJ: Long-term efficacy and safety of linagliptin in patients with type 2 diabetes and severe renal impairment: a 1-year, randomized, double-blind, placebo-controlled study. Diabetes Car 2012 [Epub ahead of print]

33. Stolar M: Glycemic control and complications in type 2 diabetes mellitus. Am J Med 2010, 123:S3-11.

34. Rizzo M, Rizvi AA, Spinas GA, Rini GB, Berneis K: Glucose lowering and anti-atherogenic effects of incretin-based therapies: GLP-1 analogues and DPP-4 inhibitors. Expert Opin Investig Drugs 2009, 18:1495-1503.

35. Johansen OE, Neubacher D, von Eynatten M, Patel S, Woerle H-J: Cardiovascular safety with linagliptin in patients with type 2 diabetes mellitus: a pre-specified, prospective, and adjudicated meta-analysis of a phase 3 programme. Cardiovasc Diabetol 2012, 11:3.

36. Hocher B, Sharkovska Y, Mark M, Klein T, Pfab T: The novel DPP-4 inhibitors linagliptin and BI 14361 reduce infarct size after myocardial ischemia/ reperfusion in rats. Inter J Cardiol 2012 [Epub ahead of print].

37. Kröller-Schön S, Knorr M, Hausding M, Oelze M, Schuff A, Schell R, Sudowe S, Scholz A, Daub S, Karbach S, Kossmann S, Gori T, Wenzel P, Schulz E, Grabbe S, Klein T, Münzel T, Daiber A: Glucose-independent improvement of vascular dysfunction in experimental sepsis by dipeptidyl-peptidase 4 inhibition. Cardiovasc Res 2012, 96(1):140-149.

38. Ring A, Graefe-Mody U, Port A, Revollo I, lovino M, Dugi KA: The DPP-4 inhibitor linagliptin does not prolong the QT interval with therapeutic and supratherapeutic doses. Br J Clin Pharmacol 2011, 72:39-50.

doi:10.1186/1758-5996-5-25

Cite this article as: Guedes et al: Linagliptin: farmacology, efficacy and safety in type 2 diabetes treatment. Diabetology \& Metabolic Syndrome 2013 5:25.

\section{Submit your next manuscript to BioMed Central and take full advantage of:}

- Convenient online submission

- Thorough peer review

- No space constraints or color figure charges

- Immediate publication on acceptance

- Inclusion in PubMed, CAS, Scopus and Google Scholar

- Research which is freely available for redistribution 